\title{
Effects of Participation in Formal Leadership Training in International Students Compared to Domestic Students: A National Study
}

\author{
Daniel A. Collier \\ Post-Doctoral Research Associate \\ Western Michigan University \\ David M. Rosch \\ Assistant Professor \\ University of Illinois at Urbana Champaign \\ Derek A. Houston \\ Visiting Assistant Professor of Adult and Higher Education \\ Oklahoma State University.
}

\begin{abstract}
International student enrollment has experienced dramatic increases on U.S. campuses. Using a national dataset, the study explores and compares international and domestic students' incoming and post-training levels of motivation to lead, leadership selfefficacy, and leadership skill using inverse-probability weighting of propensity scores to explore differences between the two samples. Unweighted findings suggest that international and domestic students enter programs similarly across in many ways, and leave the immersion program with similar gains. However, a matched-sample comparison suggests that international students' growth was statistically different in ethical leadership skills, affectiveidentity motivation to lead, and leadership self-efficacy. Discussion focuses on the benefits of leadership development to international students why campuses could build partnerships between units that serve international students and leadership educators to facilitate a more inclusive campus.
\end{abstract}

\section{Introduction}

The inclusion of international students within U.S. post-secondary institutions has long been a priority of U.S. post-secondary education. While the U.S. has traditionally been welcoming to international students, the motives for enrolling international students has recently changed. Before the 2008 recession, international students were recruited primarily to build national socio-political ties; however, since the recession, the motivation to enroll international students have shifted towards revenue generation $(\mathrm{Hu}, 2011$; Slaughter \& Cantwell, 2012). With this shift, international student enrollment has quickly expanded. In 2004, enrollment of international students was just under 600,000 total enrollees; yet, in 2014 enrollment had exploded to nearly one million students with the largest gains seen in 2014 (Institute of International Education [IIE], 2015). Attracting international students to the U.S. has become big business for both institutions and the economies they support, as international students supply tens of billions of dollars to the U.S. economy (The Association of International Educators [NAFSA], 2013).

While U.S. postsecondary institutions have modified business practices to obtain revenue from international students, research suggests that campuses may have yet to develop 
or promote adequate socio-cultural accommodations to the students themselves (Collier \& Hernandez, 2016; Greenblatt, 2005; Hu \& Kuh, 2003; Trice, 2004; Ward, 2015). Although campuses may be lagging in developing international student specific programs and interventions, emerging evidence suggests that leadership education programs may be a suitable pathway to assisting international students in interactions with domestic students and in becoming more confident, comfortable, and engaged on campus (Collier \& Rosch, 2016).

Studies suggest that international students are interested in engaging with domestic students and the communities surrounding campuses (Yuan, 2011; Bertram, Poulakis, Elsasser, \& Kumar, 2014). With most leadership development programs intentionally focused on encouraging participants to develop relationships with diverse groups and to practice leadership skills within the community (Owen, 2013), attending leadership education initiatives may be a natural way for international and domestic students to come together. Here, we utilize a national dataset set to explore the differences between international and domestic students regarding leadershipfocused skills, motivation to lead, self-efficacy, and the differential effects of leadership education programs. Data is collected from students who participated in the LeaderShape Institute, a week-long leadership development program that occurs at dozens of universities.

\section{International Student Development and Engagement on U.S. Campuses.}

Previous research has found that international students report a variety of integration issues stemming from stereotyping and racism (Chapdelaine \& Alexitch, 2004; Greenblatt, 2005; Poyrazli \& Grahame, 2007), mockery of English proficiency (Cho, 2009), and negative interactions with both domestic students and staff (Rose-Redwood \& Rose Redwood, 2013). Thus, international students have reported lower levels of confidence as compared to domestic students, which may preclude international students from engaging in class, campus, or community activities (Lee \& Rice, 2007). It is, therefore, no surprise that research has found that many international students engage in self-segregation with either conationals or other international students (Rose-Redwood \& Rose-Redwood, 2013). Such issues may lead international students to develop beliefs that campuses do not provide institutional support (Cho, 2009) as they shy away from the developmental and cultural programming that is offered by campuses (Trice, 2004).

In response, U.S. institutions have developed units aimed to serve the international student population. Such units are generally labeled International Student Services [ISS] offices. Often, ISS departments serve dual purposes (Collier \& Hernandez, 2016; Ward, 2015 ) - to support students as they navigate federal administrative processes (i.e. visas) and business procedures of the university (i.e. tuition) and to develop and promote cultural and social interaction (i.e. campus involvement activities). Evidence exists that ISS units may value the former purpose over the latter as ISS units' struggles to develop and promote interactive social and cultural programming have been most evident on campuses who support the most international students (Collier \& Hernandez, 2016). One example is found at Purdue University, where polling has suggested that $29 \%$ of international students believe there is a lack of co-curricular involvement opportunities for international students and revealed that only $15 \%$ of international students in the sample reported holding a friendship with a domestic student (Zehner, 2012). Other research has suggested that $65 \%$ of international students are either self-segregators (27\%) or exclusive global mixers (38\%) students who interact only with co-nationals and other international students (Rose-Redwood \& Rose-Redwood, 2013). 
Segregation serves as a barrier to widening multicultural perspectives (Watt, Golden, Schumacher, \& Moreno, 2013). However, increased interactions with domestic students have been shown to result in better academic performance and increased satisfaction with the collegiate experience (Webber, Krylow, \& Zhang, 2013). Thus, researchers have long been calling on institutions to inspire intentional interactions between international and domestic students (Hu \& Kuh, 2003; Greenblatt, 2005).

Undoubtedly, U.S. institutions are trying to be more integrative. One concept gaining increased attention in transforming campuses to becoming more welcoming to international students is Internalization at Home [ $\mathrm{IaH}]$. IaH conceptualizes how post-secondary institutions can more fully embrace internationalization within formal curricula, in informal curricula, and within the communities that campuses are situated in (Nilsson, 2003). Generally, IaH removes the dichotomous "us" and "them" labels and encourages campus to accept everyone as "us," and promotes a constructivist perspective where knowledge is developed in relation to personal perspectives and transfer of knowledge occurs from and between everyone in the experience (Mestenhauser, 2003).

Fortunately, many campuses may have already carved out spaces that IaH calls for, via leadership education and development programs. And while leadership development programs may not have been intentionally designed specifically with the conceptualizations of IaH concepts in mind, they were created with similarly oriented notions. For example, leadership development programs were intentionally devised to (1) promote multicultural interaction and collaboration (Komives, Longerbeam, Owen, Mainella, \& Osteen, 2006), (2) develop authentic relationships (Astin \& Astin, 2000), and (3) inspires students to more deeply engage on campuses and within communities (Cress, Astin, Zimmerman-Oster, \& Burkhardt, 2001). In combination, leadership development programs have obvious alignments with IaH and actively encourages both international and domestic students to build relationships with each other and practice leadership skills in shared spaces.

A Competency-based "Ready, Willing, and Able" Model of Leadership. In the beginning of the new millennium, Astin \& Astin (2000) challenged postsecondary leadership educators to develop better, more ethical and inclusive leaders. Since the authors' calls, formal leadership development programs on campuses have profoundly expanded (Dugan, 2011; Sessa, Matos, \& Hopkins, 2009). Many campuses now offer leadership certificates and majors, and promote opportunities to send students to formal leadership development seminars, most which (Owen, 2013) use community-oriented and relationship-based leadership models labeled as post-industrial (Rost, 1993).

We utilized a conceptual framework of leadership competency that builds on the skills of post-industrial leadership and combines the need for leadership education to additionally focus on developing participants' motivational and self-efficacy capacities as well. This framework, described as the Ready, Willing, and Able [RWA] model (Keating, Rosch, \& Burgoon, 2014) suggests that for leaders to be effective in contemporary society, they must not only develop leadership skills but also possess a threshold capacity of leadership selfefficacy and motivation to put forth efforts to lead to turn possession of skill into effective action. See Figure 1. We describe each of these capacities more fully.

Figure 1. Leadership Capacity: Being "Ready, Willing, and Able” to Lead 


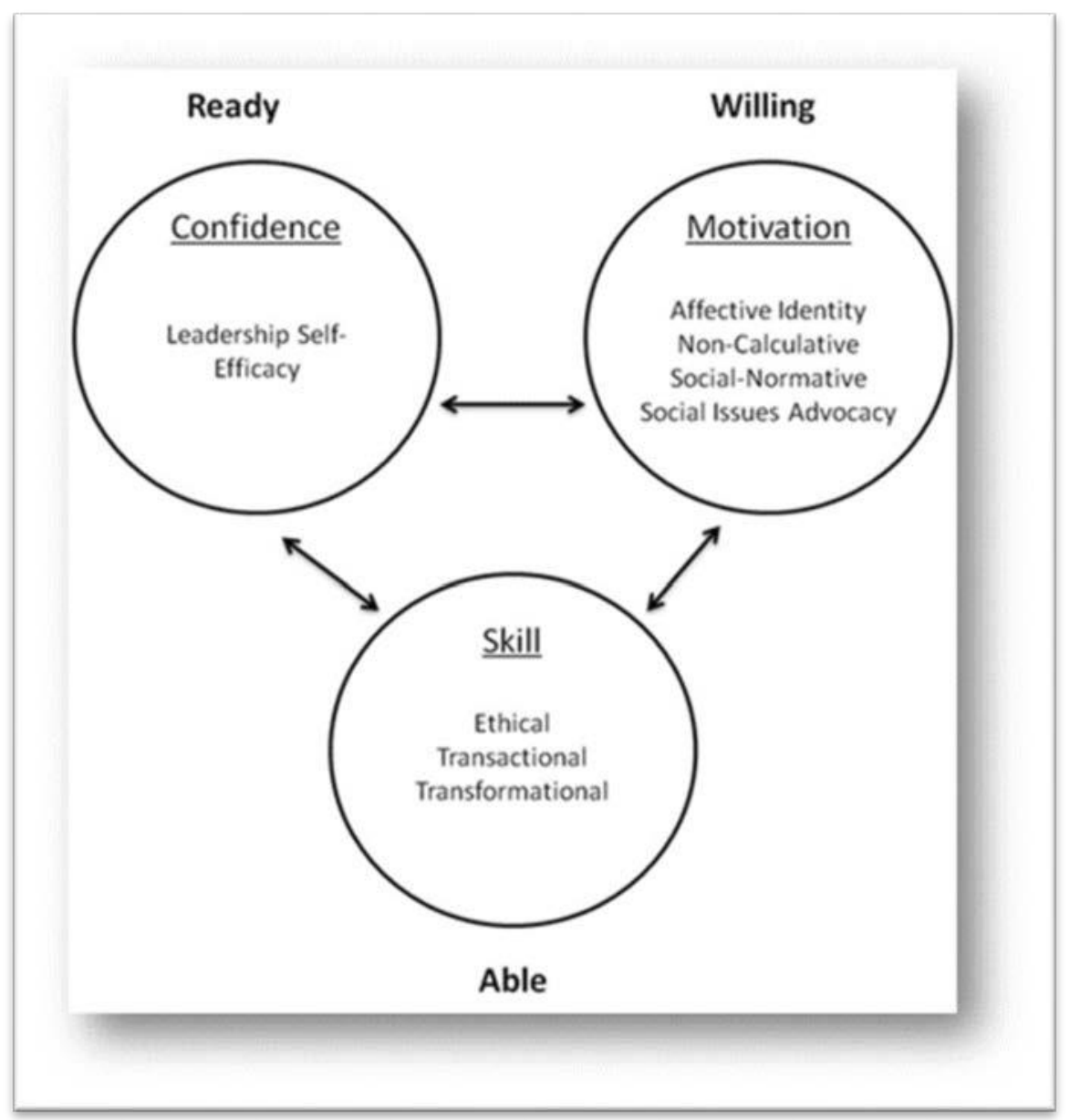

Figure 1

Leadership Skill. The RWA model utilizes the concepts of transformational and transactional leadership (Bass. 1998). Transformational leadership skills encourage leaders to develop more equalized environments where people own a shared sense of responsibility (Groves \& LaRocca, 2011; Rost, 1993) and collaboration is based upon developing authentic relationships and collective movement towards goals (Antonakis, Avolio, \& Sivasubramaniam, 2003). Previous research has found that transformational leaders promote increased team performance (Wang, Oh, Courtright, \& Colbert, 2011). In contrast, transactional leaders rely more heavily on contract-like relationships where followers work towards completing tasks in exchange for various compensations (Bass \& Avolio, 1993; Jung \& Avolio, 2000). To be noted, transactional leadership is not defined as a negative style of leadership as it still focuses on relationships and utilizing relationships to achieve goals. In addition, contemporary leaders must place significant emphasis on ethical behaviors and goals (Brown, Trevino, \& Harrison, 2005).

Leadership Self-Efficacy. The RWA model also includes the concept of leadership self-efficacy [LSE]. LSE is widely studied and has emerged as a valid measure of leadership capacity (Dugan \& Komives, 2010; Dugan, 2011). LSE refers to a leader's sense of potential for success in performing leadership activities (Murphy, 2002). Previous research has connected LSE to leader success within group contexts (Avolio, Reichard, Hannah, Walumbwa, \& Chan, 2009; Machida \& Schaubroeck, 2011) and degree of interest in possessing formal positions of 
leadership (Hannah, Avolio, Luthans, \& Harms, 2008). In university settings, increased leadership self-efficacy has been linked with students' desire to lead student-run organizations (Shertzer \& Schuh, 2004). Failing to cultivate LSE may result in the loss of interest in leading or even participating in group settings.

Motivation to-Lead. The third construct included within the RWA model is motivation to lead [MTL]. As theorized by Chan and Drasgow (2001), MTL measures the motivation that individuals hold to engage in leadership behaviors. MTL measures three connected but unique areas from where the motivation to lead may stem: (1) Affective Identity [AI], Social Normative [SN], and Non-Calculative [NC]. AI refers to the self-belief that an individual can lead and therefore should be a leader. SN is based on a sense of duty in assisting one's group to achieve its goals. $\mathrm{NC}$ refers to the level in which an individual will avoid a self-centered cost-benefit analysis in taking on leadership responsibilities (i.e. "What's in it for me?"). Individuals with enhanced non-calculative motivation to lead will often assume leadership positions and responsibilities regardless of stress, workload, or praise. Previous research has found that MTL is a predictor in increased engagement in leadership of college students (Rosch, Collier, \& Thompson, 2015; Rosch, 2014) and has been correlated with organizational effectiveness (Van Iddekinge, Ferris, \& Heffner, 2009).

\section{Purpose of Study}

The purpose of our study is to compare U.S. international students and their domestic peers in their incoming leadership capacity and change in such capacity through participation in a formal leadership program. Through the exploration, we expect to help leadership education researchers and practitioners more fully understand the effects that leadership development programs have on international students and make a case for leadership development personnel and administrators to explore leadership development experiences as avenues to make their campuses more welcoming and integrative for international students.

\section{Research Questions}

1. What differences exist between international and domestic students in incoming and posttraining measures of leadership self-efficacy, motivation to lead, and leadership skills?

2. How do international students' incoming measures of leadership self-efficacy, motivation to lead, and leadership skills change due to participation in a co-curricular leadership program?

3. To what extent do international students' change in capacity after participating in leadership programs differ from that of domestic peers?

\section{Method}

Data Collection. Data was collected in 2013 and 2014 at 21 postsecondary institutions who hosted a LeaderShape Institute (hereafter referred to as the "program") and volunteered to be part of data collection efforts. LeaderShape, Inc., is a non-profit leadership education organization that partners with institutions to deliver an intensive six-day immersive leadership development seminar. Primary outcomes associated with the program are to encourage students to: (1) build inclusive communities, (2) develop collaborative relationships, (3) create long-term leadership goals, and (4) recognize how they can positively impact the campuses, communities, and societies in which they reside. During the past four 
decades, over 30,000 students have participated in a program, while in 2014, 85 universities hosted one (www.leadershape.org).

Sample. The sample in our study consisted of 1,168 participants. Due to missing and incomplete data, the final sample is 717 participants - or $61 \%$ of the initial sample. In the balanced models, the final sample is statistically similar to the full sample based on five selfidentified demographic variables: international student status, sexual identity gender, race, and class year. Of the 717 students, 96\% $(n=688)$ identified as a U.S. domestic student. The wide disparity in size between the sample of U.S. international students and their domestic peers led us to utilize data-balancing techniques (inverse-probability weighting) to control for variation between the two. In addition, 67\% $(n=480)$ identified as female. Regarding racial identity, 58\% $(n=415)$ identified as white/Caucasian, $15 \%$ identified as AfricanAmerican/Black, 12\% identified as Asian/Asian American, $7 \%$ identified as Hispanic/Latina/o, and 6\% identified as multi-racial. Regarding class year, 30\% identified as freshman, $31 \%$ as sophomore, $29 \%$ as junior, $9 \%$ as senior, and $2 \%$ as a graduate student.

\section{Instrumentation.}

Leadership Skill. We employed the Leader Behavior Scale [LBS] (Podsakoff, MacKenzie, Moorman, \& Fetter, 1990) to ascertain participants' leadership skill. The LBS is a widely used 28 -item instrument that measures both transformational and transactional leadership skill. Within the subscale that measures transformational leadership skill, a sample item was, "When I lead a group, I show what is expected to group members." A sample item that gauged transactional leadership skill was, "I commend other group members for doing a better than average job." LBS has been utilized in business and educational settings for several decades with high internal consistencies ranging from .71 to .89 (Yukl, 2010). We also utilized the Ethical Leadership Scale [ELS], a 10-item, Likert scale instrument designed to gauge the degree to which leaders engage in ethical means to motivate people and achieve goals (Brown, Treviño, \& Harrison, 2005). An example question within the scale was, "When I make decisions in groups to which I belong, I keep other members' best interests in mind."

Leadership Self-Efficacy. To measure LSE, we used the 8-item Likert-scaled Self-Efficacy for Leadership [SEL] scale. SEL measures a person's sense of selfconfidence and assuredness when engaged in leadership behaviors (Murphy \& Fiedler, 1992). A sample item from the SEL scale was, "In general, I'm not very good at leading a group of my peers." SEL has been in utilized in business and higher education for multiple decades (Hoyt, 2005), and has shown acceptable internal reliability (Murphy \& Ensher, 1999).

Leadership Motivation. To capture students' motivation to lead, we utilized the Motivation-to-Lead [MTL] scale (Chan \& Drasgow, 2001) and a variant of the Social Issues Advocacy Scale [SIAS] (Nilsson, Marszalek, Linnemeyer, Bahner, \& Misialek, 2011). The MTL is a 27-item, Likert-scale instrument. The MTL measures three subscale motivations - Affective Identity [AI], Social Normative [SN], and Non-Calculative [NC]. Each of the subscales consists of 9 questions. Example items within each scale are: (1) Within the AI subscale,"I am the type of person who likes to be in charge of others;" (2) within the SN subscale, "I was taught to believe in the value of leading others;" and (3) within the NC subscale, "I never expect to get more 
privileges if I agree to lead a group." Recently, the MTL instrument has been introduced into higher education as a mechanism to student leadership assessment (Rosch, Collier, Thompson, 2015; Rosch, Collier, \& Zehr, 2014).

Because curriculum within the Institute focused, in part, on building inclusive organizations and communities - based on tenets of social justice - we included a modified version of the SIAS. The SIAS measures a person's motivations in and behaviors of advocating for social issues (Nilsson, et al., 2011). Initially, SIAS also included items connected to political advocacy (i.e. lobbying and voting); for this research, we eliminated such items as these behaviors were not part of the learning outcomes or curriculum within the program, and were the only items in the scale that referenced a specific context for students' social advocacy. The modified SIAS was a 12-item, Likert-scaled measure. One example of an item was, "I am personally responsible to confront friends and colleagues who display signs of discrimination." Previous research suggested that SIAS had appropriate reliability and validity (Nisson, et al., 2011).

\section{Data Analysis.}

T-test. We first conducted unweighted independent sample t-tests to compare international participants with their domestic peers on incoming and post-program scores, as well as the gains that each sample expressed (the different between their post-program and incoming scores). This analysis allowed us to assess any largescale differences across the two samples and to compare how an unweighted analysis might differ from a more statistically rigorous weighted comparison we conducted posthoc.

Inverse probability weighting. Prior studies that have used quasiexperimental designs that employ the use of propensity scores to balance their samples do so in an attempt make causal inferences about experimental effects (see Buschlen \& Dvorak, 2011; Rouse, 2012). Where this study differs is that all students in the sample participated in the leadership training. Thus, the use of quasiexperimental designs is not to make causal inferences but to provide better descriptive comparisons.

Because international students represented less than $10 \%$ of the sample, OLS estimates this group may be constrained relative to domestic students. Therefore, reweighting or balancing the sample using a propensity-score technique may provide more accurate estimates. Typical uses of propensity-score matching attempts to create 1-to-1 matched cases within treatment (i.e. leadership training) and non-treatment (i.e. non-leadership training) groups. In doing so, unmatched cases from both groups are removed from the data and estimates of the benefits of receiving training are then made from the remaining data. Propensity-score matching, utilized in this way, attempts to make a causal inference about the benefits of a treatment, leadership training in this example.

However, because citizenship status does not represent an experimental variable (i.e. we cannot manipulate one's status), we employed the propensity-score technique "inverseprobability weighting" (IPW), to create better balance between the covariates of both samples (Li, Zaslavsky, \& Landrum, 2013) and "evaluate the average difference in the outcome in two groups with balanced distributions of covariates" (Li, Morgan, \& Zaslavsky, 2014, p.4) Additionally, due to sample-size limitations, IPW was chosen because it limits the amount of 
data and sample loss (see Holmes \& Olson, 2010). Instead of matching individual cases, cases are re-weighted based on their "likelihood" of being an international student. To do this, IPW techniques are used to separately re-weight the population of domestic and international students based on each student's predicted probability (propensity score) of being an international student. The propensity of being an International student is estimated based on the logistic regression of the likelihood of being an international student as the dependent variable and a vector of demographic and incoming leadership scores as the independent variables. The predicted probabilities of the logistic regression are considered the propensity scores for each student. After conducting IPW, we used ordinary least-squares (OLS) regression is used to estimate the relationship between the dependent variables (facets of leadership growth) and international student status.

\section{Results}

\section{T-tests.}

Incoming and Post-Training Comparison. Significant differences were uncovered in Transactional Leadership skill - where domestic students $(M=4.23, S D$ $=0.52)$ had higher incoming skills than did international students $(M=4.03, S D=$ $0.52), t(712)=1.95, p=.025$. Similarly, international students $(M=3.84, S D=0.32)$ possessed lower than domestic students $(M=3.96, S D=0.36)$ incoming Transformational Leadership skill, $t(712)=1.70, p=.045$. See Table 1 .

Table 1. Incoming leadership scores

\begin{tabular}{lccccccccc}
\hline & \multicolumn{1}{c}{ Domestic Students } & \multicolumn{4}{c}{ International Students } & \multicolumn{3}{c}{ Independent T-Test } \\
Variable & $\boldsymbol{N}$ & $\boldsymbol{M}$ & $\boldsymbol{S D}$ & $\boldsymbol{N}$ & $\boldsymbol{M}$ & $\boldsymbol{S D}$ & $\boldsymbol{t}$ & $\boldsymbol{D} \boldsymbol{f}$ & $\boldsymbol{p}$ \\
Ethical Leadership Skill & 687 & 4.14 & 0.38 & 27 & 4.10 & 0.33 & 0.44 & 712 & .330 \\
Affective-identity MTL & 687 & 3.50 & 0.67 & 27 & 3.50 & 0.54 & 0.05 & 712 & .478 \\
Non-calculative MTL & 687 & 3.95 & 0.67 & 27 & 3.78 & 0.77 & 1.32 & 712 & .094 \\
Social-normative MTL & 687 & 3.92 & 0.39 & 27 & 3.80 & 0.33 & 1.47 & 712 & .071 \\
Leadership self-efficacy & 687 & 3.81 & 0.48 & 27 & 3.78 & 0.46 & 0.38 & 712 & .351 \\
Social Issues Advocacy & 687 & 3.77 & 0.50 & 27 & 3.83 & 0.42 & 0.58 & 712 & .718 \\
Transactional Skill & 687 & 4.23 & 0.52 & 27 & 4.03 & 0.52 & 1.95 & 712 & $.025^{*}$ \\
Transformational Skill & 687 & 3.96 & 0.36 & 27 & 3.84 & 0.32 & 1.70 & 712 & $.045^{*}$ \\
\hline
\end{tabular}

$* p<.05, * * p<.01$

Other than domestic students' $(M=4.30, S D=0.36)$ elevated capacity in the area of transformational leadership skill compared to international peers $(M=4.11, S D=0.57, t(674)$ $=2.56, p=.005)$, no differences emerged in a comparison participants' post-training leadership capacities. See Table 2. 
Table 2. Post-program leadership scores

\begin{tabular}{lcccccccccc}
\hline \multicolumn{1}{c}{ Variable } & \multicolumn{1}{c}{ Domestic Students } & \multicolumn{4}{c}{ International Students } & \multicolumn{3}{c}{ Independent t-test } \\
Ethical Leadership Skill & $\boldsymbol{N}$ & $\boldsymbol{M}$ & $\boldsymbol{S D}$ & $\boldsymbol{N}$ & $\boldsymbol{M}$ & $\boldsymbol{S D}$ & $\boldsymbol{t}$ & $\boldsymbol{D} \boldsymbol{f}$ & $\boldsymbol{P}$ \\
Affective-identity MTL & 662 & 4.37 & 0.40 & 27 & 4.25 & 0.47 & 1.57 & 687 & .058 \\
Non-calculative MTL & 673 & 3.50 & 0.71 & 26 & 3.32 & 0.71 & 1.27 & 697 & .110 \\
Social-normative MTL & 663 & 3.99 & 0.41 & 26 & 4.02 & 0.39 & 0.35 & 687 & .636 \\
Leadership self-efficacy & 657 & 4.20 & 0.45 & 26 & 4.15 & 0.66 & 0.48 & 681 & .315 \\
Social Issues Advocacy & 660 & 4.17 & 0.51 & 27 & 4.14 & 0.49 & 0.29 & 685 & .384 \\
Transactional Skill & 666 & 4.43 & 0.54 & 27 & 4.34 & 0.56 & 0.82 & 691 & .207 \\
Transformational Skill & 650 & 4.30 & 0.36 & 26 & 4.11 & 0.57 & 2.56 & 674 & $.005^{*}$ \\
\hline
\end{tabular}

$* p<.05, * * p<.01$

\section{Unmatched, Un-weighted Growth from Pre-to-Post Reported Scores and Differences.}

Two-sample t-tests were to test the null hypotheses that the average growth (Growth is measured by taking the difference of the composite measures from the pre- and postassessment.) across multiple leadership measures is different between domestic and international students. Of the eight leadership constructs, no significant differenced emerged between international and domestic students. See Table 3 - Gains from in leadership scores.

Table 3. Gains in leadership scores

\begin{tabular}{lccccccccc}
\hline & \multicolumn{4}{c}{ Domestic Students } & \multicolumn{4}{c}{ International Students } & \multicolumn{3}{c}{ Independent t-test } \\
\multicolumn{1}{c}{ Variable } & $\boldsymbol{N}$ & $\boldsymbol{M}$ & $\boldsymbol{S D}$ & $\boldsymbol{N}$ & $\boldsymbol{M}$ & $\boldsymbol{S D}$ & $\boldsymbol{t}$ & $\boldsymbol{d} \boldsymbol{f}$ & $\boldsymbol{p}$ \\
Ethical Leadership Skill & 662 & .236 & .372 & 27 & .148 & .406 & 1.20 & 687 & .115 \\
Affective-identity I MTL & 673 & .009 & .581 & 26 & -.162 & .400 & 1.48 & 697 & .069 \\
Non-calculative MTL & 679 & .236 & .652 & 27 & .296 & .542 & 0.48 & 704 & .683 \\
Social-normative MTL & 663 & .074 & .400 & 26 & .231 & .358 & 1.97 & 687 & .975 \\
Leadership self-efficacy & 657 & .387 & .503 & 26 & .400 & .477 & 0.13 & 681 & .551 \\
Social Issues Advocacy & 660 & .397 & .467 & 27 & .312 & .395 & 0.94 & 685 & .175 \\
Transactional Skill & 666 & .203 & .527 & 27 & .315 & .583 & 1.08 & 691 & .859 \\
Transformational Skill & 650 & .350 & .361 & 26 & .285 & .425 & 0.90 & 674 & .185 \\
\hline
\end{tabular}

$* p<.05, * * p<.01$

Matched, Weighted Sample OLS Regressions. Reweighting the sample, in most cases, reduced the standard errors of the independent variable (international status) and increased the proportion of the variance explained by the model, indicating that the IPTW models fit the data better than the non-weighted models. Across seven of the eight leadership constructs, there was a statistically significant increase in the average growth for all students. On average, all students, regardless of international status, reported some growth in most areas.

The growth of international students was significantly different from domestic students in three of the eight leadership constructs. On average, growth in ethical skill and affective-identity motivation to lead for international students was less than domestic students (note the negative beta weight for "Inter" in the appropriate row for Table 4). However, for 
international students, growth in leadership self-efficacy was higher compared to domestic students. All of our regression statistics can be found in Table 4.

Table 4. Ordinary-least-squares regression statistics.

\begin{tabular}{|c|c|c|c|c|c|c|c|}
\hline \multirow{4}{*}{ Ethical Leadership skills } & & \multicolumn{3}{|c|}{ Un-Weighted } & \multicolumn{3}{|c|}{ Weighted } \\
\hline & \multirow{3}{*}{$\begin{array}{l}\text { Inter } \\
\text { _cons }\end{array}$} & \multirow{3}{*}{$\begin{array}{c}\mathrm{B} \\
-0.07 \\
0.23\end{array}$} & \multirow{3}{*}{$\begin{array}{l}\text { S.E } \\
0.07 \\
0.01\end{array}$} & \multirow{3}{*}{$\begin{array}{l}P \\
* * *\end{array}$} & \multirow{3}{*}{$\begin{array}{c}\mathrm{B} \\
-0.10 \\
0.24\end{array}$} & \multirow{3}{*}{$\begin{array}{l}\text { S.E } \\
0.03 \\
0.02\end{array}$} & \multirow{3}{*}{$\begin{array}{r}P \\
* * * \\
* * *\end{array}$} \\
\hline & & & & & & & \\
\hline & & & & & & & \\
\hline \multirow[t]{2}{*}{ Affective-identity MTL } & Inter & -0.16 & 0.11 & & -0.13 & 0.04 & $* *$ \\
\hline & _cons & 0.01 & 0.02 & & 0.00 & 0.03 & \\
\hline \multirow[t]{2}{*}{ Non-calculative MTL } & Inter & 0.06 & 0.12 & & -0.02 & 0.04 & \\
\hline & _cons & 0.23 & 0.02 & $* * *$ & 0.24 & 0.03 & $* * *$ \\
\hline \multirow[t]{2}{*}{ Social-normative MTL } & Inter & 0.16 & 0.08 & & -0.04 & 0.03 & \\
\hline & _cons & 0.07 & 0.02 & $* * *$ & 0.08 & 0.02 & $* *$ \\
\hline \multirow[t]{2}{*}{ Leadership self-efficacy } & Inter & 0.00 & 0.10 & & 0.14 & 0.04 & $* * *$ \\
\hline & _cons & 0.39 & 0.02 & $* * *$ & 0.39 & 0.03 & $* * *$ \\
\hline \multirow[t]{2}{*}{ Social issues advocacy } & inter & -0.07 & 0.09 & & -0.05 & 0.03 & \\
\hline & _cons & 0.40 & 0.02 & $* * *$ & 0.39 & 0.02 & $* * *$ \\
\hline \multirow[t]{2}{*}{ Transactional skill } & inter & 0.10 & 0.10 & & 0.06 & 0.03 & \\
\hline & _cons & 0.20 & 0.02 & $* * *$ & 0.21 & 0.03 & $* * *$ \\
\hline \multirow[t]{2}{*}{ Transformational skill } & inter & -0.05 & 0.07 & & -0.03 & 0.03 & \\
\hline & _cons & 0.35 & 0.01 & $* * *$ & 0.35 & 0.02 & $* * *$ \\
\hline
\end{tabular}

$* p<.05, * * p<.01, * * * p<.001$

\section{Discussion}

Overall the findings of the research have implications for both leadership educators and administrators interested in finding new pathways towards developing more inclusive campuses. We have found that as compared to domestic students, international students entered leadership programs with statistically similar self-reported leadership skill, efficacy, social justice awareness, and motivation to lead. Additionally, as compared to domestic students, international students' post-program scores were statistically similar in all areas except for transformational leadership skill, where domestic students' scores were noticeably higher, supporting past research showing similar findings (Collier \& Rosch, 2016).

However, a more rigorous investigation yielded different results. Matched and weighted OLS regression results suggest such similarities may not be the case when comparing international students to domestic peers in regards to effects on their participation 
in leadership programs. With balanced data, our models indicate that international students trail behind domestic students in growth in ethical leadership skill and affective-identity motivation to lead, while outpacing domestic students in developing a leadership-focused sense of self-efficacy. This finding suggests that programs focused on broad-based leadership development, popular on many university campuses, may leave international students more confident in their leadership skills, but lagging in a sense of themselves as leaders and able to act ethically regardless of outside pressure.

Potentially, leadership educators could act upon international students' heightened self-efficacy and assist these students in developing pathways in becoming leaders in student organizations. Likely, increased practice will also further develop international students' affective-identity and ethical practices. Additionally, leadership development professionals could develop small-scale workshops or experiences explicitly focused on bolstering affective-identity and ethical leadership behaviors. Because leadership education is designed to be inclusive and such designs align with $\mathrm{IaH}$, we suggest that these workshops integrate international and domestic students.

Theoretically, increased leadership self-efficacy capacity may encourage international students to explore additional opportunities to develop leadership capabilities and practice leadership skill. Continued engagement in leadership development may naturally lead to improved engagement with campus programs with domestic students, and thus, become less self-segregated (Du \& Wei, 2015; Rose-Redwood \& Rose Redwood, 2013). Possibly, leadership development programs' influence on the leadership self-efficacy of both international and domestic students could represent the steps required to reduce or eliminate cultural boundaries often found in both international and domestic students.

Whereas some differences emerged across the two populations, similarities were discovered in both the degree and growth of leadership capacity measured. Importantly, together domestic and international students showed similar commitment to: (1) social justice processes - like protecting each other from discrimination, (2) buying into group processes and sharing responsibilities with each other, and (3) developing enhanced skills within a leadership paradigm that generally encourages the cultivation of authentic, trusting relationships amongst team members.

Like many modern leadership development curricula employed on campuses, the curriculum within the leadership program we studied was intentionally designed with constructivist elements integrated into the experience - in that students were encouraged to share their personal experiences and points of view, especially in small groups. Students are expected to assemble commonly agreed principles and sometimes shift their personal belief systems - exactly as IaH calls for (Mestenhauser, 2003). This study's findings imply that together both groups of students may have become more aware of each other's experiences and culture, have learned how to develop deeper relationships with each other, and are likely more open towards the idea of and more confident in interacting with each other.

As the LeaderShape Institute employs curricula and desired developmental outcomes that are not dramatically dissimilar to programs many campuses usually offer, our results suggest that campus units aimed to serve international students should purposefully steer international students towards leadership development programs. With recent studies suggesting that units serving international students may be more focused on business functions associated with serving this population (Collier \& Hernandez, 2016; Ward, 2015; 
Zehner, 2012), we believe that these units would benefit from partnerships with leadership education units. This partnership could assist international student serving units with outcomes associated with social development and campus involvement; which in combination are important elements of IaH (Mestenhauser, 2003) and desired outcomes of many researchers who focus on international students (Hu \& Kuh, 2003; Greenblatt, 2005; Webber, Krylow, \& Zhang, 2013).

\section{Future Research and Limitations}

Future research could travel several pathways. First, more data is needed. More research including other leadership development programs would possibly solidify the emerging trend and larger samples would allow us to speak more confidently about the effects of leadership education programs on international students. Next, as we have gained traction in exploring the pre-to-post leadership program experiences, one limitation the study possesses is in the inability to measure lagged survey data or in qualitative follow-up to explore how students have become more involved or if they have developed tighter relationships with between domestic and international student groups.

There are many questions to ponder moving forward. Do international students still prefer to self-segregate or co-mingle with only other nationals or have they become more comfortable in engaging with domestic students? Are domestic students more comfortable in collaboration and in building relationships with international students? There is still much work to be done in exploring how Leadershape and other immersive leadership development programs affect international students' behaviors.

Finally, the numbers of international students were low compared to domestic students. However, drawing from the researchers' previous experiences with LeaderShape, each university employs a different process to invite their students to join the program. Some select students via application others approach students to engage. Often, because departments cover the costs of the program this process is rather competitive. Although international student engagement in LeaderShape is low, at least in our previous research focused on an institution with a large international student population that regularly hosts leadership development programs open to the whole study body, international students show an elevated desire to engage in these programs (Collier \& Rosch, 2016). In the future, research could more deeply explore and bring to light the various LeaderShape recruitment processes each institution employees. Such an investigation may answer the question posed by reviewers.

\section{Conclusion}

The current study follows another that suggests that after engaging with a leadership development program, international students generally make gains across most scales and that gains are like domestic peers (Collier \& Rosch, 2016). Leadership education programs have long demonstrated various positive effects on domestic students (Dugan \& Komives, 2010; Dugan, 2011; Rosch, Stephens, \& Collins, 2016) and now research is beginning to uncover similar trends in international students. Such findings are highly encouraging especially when considering that contemporary leadership education already promotes concepts that closely link with IaH and with the development an inclusive, accepting community. 
Overall, the study provides an additional level of evidence suggesting leadership development programs may become a catalyst in helping U.S. campuses develop more inclusive communities. The data indicates that immersive leadership development programs like the LeaderShape Institute generate comfortable and inclusive environments that allow international students to engage within and report generally similar developmental outcomes as domestic students. Because of the general lack of differences in growth, international students are signaling that leadership development programs are establishing environments where they usually feel comfortable, safe, and supported in their interactions with domestic students. These signals suggest that leadership development could be a useful tool for campuses in supporting their growing international student populations' integration and in building more inclusive communities. We implore the researchers to broaden the findings and practitioners to explore potential pathways between leadership development programs and units that serve international students.

\section{References}

Antonakis, J., Avolio, B.J., \& Sivasubramaniam, N. (2003). Context and leadership: An examination of the nine-factor full-range leadership theory using the multifactor leadership questionnaire. The Leadership Quarterly, 14(3), 261-295. http://dx.doi.org/10.1016/S1048-9843(03)00030-4

Astin, A.W., \& Astin, H.S. (2000). Leadership reconsidered: Engaging higher education in social change. Battle Creek, MI: W.K. Kellogg Foundation.

Association of International Educators. (2013). The economic benefit of international students: \$26.8 billion contributed; 340,00 U.S. jobs supported. Retrieved from http://www.nafsa.org/_/file/_/eis2014/usa.pdf

Avolio, B. J., Reichard, R. J., Hannah, S. T., Walumbwa, F. O., \& Chan, A. (2009). A metaanalytic review of leadership impact research: Experimental and quasi-experimental studies. The Leadership Quarterly, 20(5), 764-784.

http://doi.org/10.1016/j.leaqua.2009.06.006

Bass, B.M. (1998). Transformational Leadership. Hillsdale, NJ: Erlbaum.

Bass, B.M., \& Avolio, B.J. (1993). Transformational leadership and organizational culture. Public Administration Quarterly, 17(1), 112-121. http://www.jstor.org/stable/40862298

Bertram, D. M., Poulakis, M., Elsasser, B. S., \& Kumar, E. (2014). Social Support and Acculturation in Chinese International Students. Journal of Multicultural Counseling and Development, 42(2), 107-124. doi:10.1002/j.2161-1912.2014.00048.x

Brown, M. E., Treviño, L. K., \& Harrison, D. A. (2005). Ethical leadership: A social learning perspective for construct development and testing. Organizational Behavior and Human Decision Processes, 97(2), 117-134. http://dx.doi.org/10.1016/j.obhdp.2005.03.002

Buschlen, E., \& Dvorak, R. (2011). The social change models as pedagogy: Examining undergraduate leadership growth. Journal of Leadership Education, 10(2), 38-56. 
Chan, K.-Y., \& Drasgow, F. (2001). Toward a theory of individual differences and leadership: Understanding the motivation to lead. Journal of Applied Psychology, 86(3), 481-498.

Chapdelaine, R.F., \& Alexitch, L.R. (2004). Social skills difficulty: Model of culture shock for international graduate students. Journal of College Student Development, 45(2), 167-184. doi:10.1353/csd.2004.0021

Cho, P.L. (2009). Welcome to America?: The perceptions of discrimination experienced by international students (Doctoral dissertation). Available from ScholarWorks@UNO. (Paper 918). Retrieved from http://scholarworks.uno.edu/cgi/viewcontent.cgi?article=1899\&context=td

Collier, D.A., \& Hernandez, X. (2016). Tatemae and honne: Interpreting the theory versus practice of international student development and outreach. Journal of Diversity in Higher Education. http://dx.doi.org/10.1037/dhe0000011

Collier, D.A., \& Rosch, D.A. (2016). Effects associated with leadership program participation in international students compared to domestic students. Journal of Leadership Education, 15(4), 33-49. doi: 1012806/V15/I4/R3

Cress, C. M., Astin, H., Zimmerman-Oster, K., \& Burkhardt, J. C. (2001). Developmental outcomes of college students' involvement in leadership activities. Journal of College Student Development, 42(1), 15-27.

Du, Y. \& Wei, M. (2015), Acculturation, Enculturation, Social Connectedness, and Subjective Well-Being Among Chinese International Students, The Counseling Psychologist, 299-325. doi: 10.1177/001100001456571

Dugan, J.P, \& Komives, S.R. (2010). Influences on college students' capacities for social responsible leadership. Journal of College Student Development, 51(5), 525-549. doi:10.1353/csd.2010.0009

Dugan, J.P. (2011). Pervasive myths in leadership development: Unpacking constraints on leadership learning. Journal of Leadership Studies, 5(2), 79-84. doi: 10.1002/jls.20223.

Greenblatt, S. (2005). International students and diversity in American higher education: Implications for internationalization. International Journal of Diversity in Organisations, Communities and Nations, 5(2), 163-171.

Groves, K.S. \& LaRocca, M.A. (2011). An empirical study of leader ethical values, transformational and transactional leadership, and follower attitudes toward corporate social responsibility. Journal of Business Ethics, 103, 511-528. 10.1007/s10551011-0877-y

Hannah, S.T., Avolio, B.J., Luthanns, F., \& Harms, P. (2008). Leadership efficacy: Review and future directions. Leadership Quarterly, 19, 669-692.

doi:10.1016/j.leaqua.2008.09.007 
Holmes, W. \& Olsen, L.J. (2010). Using propensity scores with small samples. Paper presented at annual meetings of the American Evaluation Association. San Antonio, Texas. Retrieved from https://www.researchgate.net/publication/268214183_USING_PROPENSITY_SCOR ES_WITH_SMALL_SAMPLES

Hoyt, C. L. (2005). The role of leadership efficacy and stereotype activation in women's identification with leadership. Journal of Leadership and Organizational Studies, 11(4), 2-14. doi:10.1177/1368430207084718

Hu, S., \& Kuh, G.D. (2003). Diversity experiences and college student learning personal development. Journal of College Student Development, 44(2), 320-334. doi:10.1353/csd.2003.0026

Institute of International Education. (2013). Open doors data: Special reports economic impact of international students. Retrieved from http://www.iie.org/Research-andPublications/Open-Doors/Data/Economic-Impact-of-International-Students/

Jung, D.I., \& Avolio, B.J. (2000). Opening the black box: An experimental investigation of the mediating effects of trust and value congruence on transformational and transactional leadership. Journal of Organizational Behavior, 21, 949-964. http://ww.jstor.org/stable/3100363

Keating, K., Rosch, D.M., Burgoon, L. (2014). Developmental readiness for leadership: The differential effects of leadership courses on creating, "ready, willing and able" leaders. Journal of Leadership Education, 13(3), 1-16. Retrieved from http://www.leadershipeducators.org/Resources/Documents/jole/2014_summer/13_3ke ating117.pdf

Komives, S.R., Longerbeam, S.D., Owen, J.E., Mainella, F.C., \& Osteen, L. (2006). A leadership identity development model: Applications from a grounded theory. Journal of College Student Development, 47(4), 401-418.

Lee, J. J., \& Rice, C. (2007). Welcome to America? International student perceptions of discrimination. Higher Education, 53, 381-409. doi:10.1007/s10734-005-4508-3

Li, F., Zaslavsky, A. M., \& Landrum, M. B. (2013). Propensity score weighting with multilevel data. Statistics in Medicine, 32(19), 3373 - 3387. doi:10.1002/sim.5786.

Li, F., Morgan, K. L., \& Zaslavsky, A. M. (2014). Balancing covariates via propensity score weighting. arXiv preprint arXiv:1404.1785. doi:10.1080/01621459.2016.1260466

Machida, M., \& Schaubroeck, J. (2011). The Role of Self-Efficacy Beliefs in Leader Development. Journal of Leadership \& Organizational Studies, 18(4), 459-468. http://doi.org/10.1177/1548051811404419

Mestenhauser, J.A. (2003). Building bridges. NAFTA, Summer, 6-11. Retrieved from https://www.nafsa.org/_/File/_/buildingbridgtesie_summer03.pdf 
Murphy, S. E. (2002). Leader self-regulation: The role of self-efficacy and multiple intelligences. In R. E. Riggio, S. E. Murphy, \& F. J. Pirozzolo (Eds.), Multiple intelligences and leadership, LEA's organization and management series (pp. 163186). Mahwah, NJ: Lawrence Erlbaum Associates.

Murphy, S. E., \& Ensher, E. A. (1999). The Effects of Leader and Subordinate Characteristics in the Development of Leader-Member Exchange Quality. Journal of Applied Social Psychology, 29(7), 1371-1394. http://doi.org/10.1111/j.15591816.1999.tb00144.x

Murphy, S. E., \& Fiedler, F. E. (1992). The contribution of leadership experience and selfefficacy to group performance under evaluation apprehension. University of Washington, United States -- Washington. Retrieved from http://search.proquest.com/docview/304005264?accountid=14553

Nilsson, B. (2003). Internationalization at home from a Swedish perspective: The case of Malmo. Journal of Studies in International Education, 7(1), 27-40. doi: 10.1177/1028315302250178

Nilsson, J. E., Marszalek, J. M., Linnemeyer, R. M., Bahner, A. D., \& Misialek, L. H. (2011). Development and Assessment of the Social Issues Advocacy Scale. Educational and Psychological Measurement, 71(1), 258-275. http://doi.org/10.1177/0013164410391581

Owen, J.E. (2013). Examining the design and delivery of collegiate student leadership development programs. College Park, MD: National Clearinghouse for Leadership Programs.

Podsakoff, P.M., Mackenzie, S.B., Moorman, R.H., \& Fetter, R. (1990). Transformational leader behaviors and their effects on followers' trust in leader, satisfaction, and organizational citizenship behaviors. The Leadership Quarterly, 1(2), 107-142. doi: 10.1016/1048-9843(90)90009-7

Poyrazli, S., \& Grahame, K.M. (2007). Barriers to adjustment: Needs of international students within a semi-urban campus community. Journal of Instructional Psychology, 34(1), 28-45.

Rosch, D. (2014). Predicting Student Leadership in Agricultural Professional Preparation Programs. NACTA Journal, 58(1), 7-10.

Rosch, D.M., Collier, D.A., \& Thompson, S.E. (2015). An exploration of students' motivation to lead: An analysis by race, gender, and student leadership behaviors. Journal of College Student Development, 56(3), 286-291. https://doi.org/10.1353/csd.2015.0031

Rosch, D.M., Collier, D.A., \& Zehr, S.M. (2014). Self-vs.-teammate assessment of leadership competence: The effects of gender, leadership self-efficacy, and motivation to lead. Journal of Leadership Education, 13(2), 96-124. 
Rosch, D.M., Stephens, C.M., \& Collins, J.D. (2015). Lessons that last: LeaderShape-related gains in student leadership capacity over time. Journal of Leadership Education, 15(1), 44-59.

Rouse, K.E. (2012). The impact of high school leadership on subsequent educational attainment. Social Science Quarterly, 93(1), 110-129. doi: 10.1111/j.15406237.2011.00836.x

Rose-Redwood, C.A., \& Rose-Redwood, R.S. (2013). Self-segregation or global mixing?: Social interactions and the international student experience. Journal of College Student Development, 54(4), 413-429.

Rost, J.C. (1993). Leadership for the $21^{\text {st }}$ Century. Westport, CT: Praeger Publishers.

Sessa, V. I., Matos, C., \& Hopkins, C. A. (2009). Evaluating a college leadership course: What do students learn in a leadership course with a service-learning component and how deeply do they learn it? Journal of Leadership Education, 7(3), 167-200.

Shertzer, J.E., \& Schuh, J.H. (2004). College student perceptions of leadership: Empowering and constraining beliefs. NASPA Journal, 42(1), 111-131. http://dx.doi.org/10.2202/1949-6605.1417

Slaughter, S. \& Cantewell, B. (2012). Transatlantic moves to the market: The United States and the European Union, Higher Education, 63, 583-606. http://www.jstor.org/stable/41429102

Stuart. E.A. (2010). Matching methods for causal inference: A review and a look forward. Statistical Science, 25(1), 1-21.

Trice, A.G. (2004). Mixing it up: Graduate international students' social interactions with American students. Journal of College Student Development, 45, 671-687. https://muse.jhu.edu/article/175655

Van Iddekinge, C. H., Ferris, G. R., \& Heffner, T. S. (2009). Test of a multistage model of distal and proximal antecedents of leader performance. Personnel Psychology, 62(3), 463-495. http://doi.org/10.1111/j.1744-6570.2009.01145.x

Wang, G., Oh, I., Courtright, S.H., \& Colbert, A.C. (2011). Performance across criteria and levels: A meta-analytic review of 25 years of research. Group \& Organization Management, 36(2), 223-270. doi: 10.1177/1059601111401017

Ward, H.H. (2015). Internationalizing the co-curriculum: Part one - integrating international students. American Council on Education. Retrieved from http://www.acenet.edu/news-room/Documents/Intlz-In-Action-Intlz-Co-CurriculumPart-1.pdf

Watt, S.K., Golden, M., Schumacher, L.A.P. \& Moreno, L.S. (2013). Courage in multicultural initiatives. New Directions in Student Services, 2013(144), 57-68. doi: 10.1002/ss.20069 
Webber, K.L., Krylow, R.B., \& Zhang, Q. (2013). Does involvement really matter? Indicators of college student success and satisfaction. Journal of College Student Development, 54(6), 591-611.

Yuan, W. (2011). Academic and Cultural Experiences of Chinese Students at an American University: A Qualitative Study. Intercultural Communication Studies, 1, 141-158. Retrieved May $1^{\text {st }} 2016$ from http://web.uri.edu/iaics/files/11WenliYuan.pdf

Yukl, G. (2010). Leadership in organizations ( $7^{\text {th }}$ edition). Upper Saddle River, NJ: Prentice Hall.

Zehner, A. (2012). Nothing to do \& no time to do it: A study of students who fail to get involved in co-curricular activities. Purdue University Student Affairs. Retrieved from:

http://www.purdue.edu/vpsa/assessment/archives/Nothing\%20to\%20do\%20and\%20n o\%20time $\% 20$ to $\% 20 \mathrm{do} \% 20 \mathrm{it}$.pdf

\section{Author Biographies}

Dr. Daniel A. Collier is currently employed at Western Michigan University as a Post-Doctoral Research Associate in the Center for Research on Instructional Change in Postsecondary Education. Daniel is an alumnus of the University of Illinois, Roosevelt University, Bradley University, and Elgin Community College. Daniel's research agenda is focused on higher education policy and politics as well as college student leadership development. Within leadership development, Daniel's work has been published in the Journal of Leadership Education and Journal of Leadership Studies and has been presented at various national conferences. Daniel can be contacted at Daniel.Collier@wmich.edu.

Dr. David M. Rosch serves as an Assistant Professor at the University of Illinois at Urbana Champaign. His particular areas of interest include programmatic training in leadership development and the accurate assessment of leadership effectiveness in student and professional organizations. He earned a Ph.D. in Higher Postsecondary Education from Syracuse University, a M.S. in Student Affairs in Higher Education from Colorado State University, and a B.A. in Psychology from Binghamton University (NY). David can be contacted at dmrosch@illinois.edu.

Dr. Derek A. Houston is a Visiting Assistant Professor of Adult and Higher Education at Oklahoma State University. Dr. Houston earned his doctorate the University of Illinois at Urbana-Champaign in the Department of Educational Leadership and Policy Studies. His areas of specialization and interest include quantitative methods, equity in intercollegiate athletics, equity and access relative to the P-20 educational pipeline, education finance policy, and sociology of education. Derek can be contacted at Derek.a.houston@ou.edu. 